\title{
Privatization of School Education: Problems and Prospects
}

\section{OPEN ACCESS}

Manuscript ID:

EDU-2021-09033897

Volume: 9

Issue: 3

Month: June

Year: 2021

P-ISSN: 2320-2653

E-ISSN: 2582-1334

Received: 12.04.2021

Accepted: 21.05.2021

Published: 01.06.2021

Citation:

Lhungdim, Mercy

Lamneichong, and E.

Hangsing. "Privatization

of School Education:

Problems and Prospects."

Shanlax International

Journal of Education, vol. 9, no. 3, 2021, pp. 261-267.

DOI:

https://doi.org/10.34293/ education.v9i3.3897

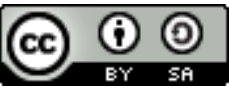

This work is licensed under a Creative Commons Attribution-ShareAlike 4.0 International License

\section{Mercy Lamneichong Lhungdim}

Research Scholar, Department of Education

Rajiv Gandhi University, Arunachal Pradesh, India

Ditps://orcid.org/0000-0002-0043-623X

\section{E. Hangsing}

Professor, Department of Education, Rajiv Gandhi University, Arunachal Pradesh, India

https://orcid.org/0000-0001-5696-3541

\section{Abstract}

Privatization has grown tremendously in the field of education in India to meet the growing demands for education in society. Privatization of education refers to the transfer of provision of education from the state to private providers with the overall policy goals- (i) Increasing access to and participation in basic education, (ii) Improving learning outcomes and overall efficiency and (iii) Improving equity in educational opportunities (Pedró, et al., 2015). School Education plays an important role in shaping the future of the nation by facilitating all-round development of the student. Keeping in view the increasing popularity and rapid growth of a number of private schools and contributions it made to society also comes with its problems. It is equally important on pragmatic grounds to examine the move towards privatization and its problems. In light of this, the present paper attempts to analyse the problems and prospects of privatization of school education as perceived by parents, teachers and students with special reference to Churachandpur District, Manipur.

Keywords: Churachandpur district, Manipur, Privatization, Problems, Prospects, School education

\section{Introduction}

Privatization has brought about rapid change in the educational scenario of India. So, everyone gives importance to private institutions. The demand for quality education has increased, especially after the state governments cannot meet the increasing demand of the society. Therefore, it encourages individuals and organisations to establish private schools. However, the emergence of market forces in educational systems has also led to more competitive environments for schools (Foskett, 2002). And Survival of many private schools depends on their ability to recruit new students and retain existing ones (Davis \& Ellison, 1997). In the context of Manipur, there is also now growing evidence that private schools are better than government schools as visible by more and more parents choosing private school education for their children, a choice borne out of the poor standard of teaching in government schools. State schools across India not only in Manipur, are failing and losing out to private schools. Children in the 6 to 14 age group attending private schools in rural areas have risen from $18.7 \%$ in 2006 to $30.8 \%$ in 2014. Private schools in the Churachandpur district have been playing a major role in producing quality education in Manipur. Churachandpur district boasts a high literacy rate of $74.67 \%$ (2011 Census), above the state literacy average of $68.87 \%$ and the Indian average of $64 \%$. 
Private schools in the Churachandpur district have shown, consecutively, over the last seven years, better examination results in Board Examinations (Board of Secondary Education Examination Manipur Result, 2009-2016). Although these schools have a good reputation, it also suffers from problems which can be analyzed from the perceptions of parents, teachers and students.

\section{Literature Review}

A literature review's based study has been carried out to identify the Problems and Prospects of Privatization of School Education. At present, many studies assess different opinions regards to the topic. A study prepared by Beavis (2004) reported the findings related to family background factors to be associated with parents who chose private. Parents who had dissatisfaction with the public schools usually sent their children to private schools. Yaacob, et al., (2014) reported that the school performances in Selangor, Malaysia become one of the reasons influencing parents' decision in choosing private schools. The parents agreed that school academic performances contributed to the school's reputation which is going to attract them in selecting the school. The school's academic performance was important for the parents as they trust the school to ensure the children's future education. Sarwar, et al., (2016) also reported that the respondent's (parents) opinion about the reasons for selecting private schools, 61.7 percent of them agreed that the private schools had a better quality of education.

\section{Objectives}

- To study the problems of private schools in terms of infrastructural facilities, activities and services for students and school management as perceived by parents, teachers and students in Churachandpur District, Manipur.

- To identify the prospects of private schools in Churachandpur district, Manipur as perceived by parents, teachers and students.

\section{Research Questions}

- What are the problems of private schools in terms of infrastructures, activities and services for students, guidance services and school management as perceived by parents, teachers and students in Churachandpur District, Manipur?

- What are the prospects of private schools in Churachandpur district, Manipur as perceived by parents, teachers and students?

\section{Research Methodology \\ Method}

Descriptive survey method was adopted for the present study.

\section{Population}

169 private schools in Churachandpur District.

\section{Sample}

Out of 169 private schools in the Churachandpur district, 79 schools ( $46.75 \%$ of the total population) were selected through a simple random sampling technique. Proportionate stratified random sampling was adopted for the selection of parents, teachers and students. The final sample size comprised 120 (Out of which there were 40 parents, 40 teachers, and 40 students).

\section{Tools Used}

A self-developed Questionnaire was used to study the problems and prospects of private schools in Churachandpur District. 7 statements were used to analyzed the problems of Infrastructural facilities, activities and services for students (3 statements), School Management (2 statements) and prospects of private schools ( 7 statements) as perceived by parents, teachers and students.

\section{Analysis}

The responses of the parents, teachers and students were analyzed qualitatively.

\section{Objective 1}

To study the problems of private schools in terms of infrastructural facilities, activities and services for students and school management as perceived by parents, teachers and students in Churachandpur District, Manipur. 
Analysis and Interpretation

Table 1: Responses about Infrastructural Facilities Infrastructural Facilities

\begin{tabular}{|c|c|c|c|c|c|}
\hline Items & Responses & $\begin{array}{l}\text { No. of Parents } \\
\&(\%) \\
\end{array}$ & $\begin{array}{c}\text { No. of Teachers } \\
\&(\%)\end{array}$ & $\begin{array}{c}\text { No. of Students } \\
\&(\%) \\
\end{array}$ & $\begin{array}{c}\text { Overall total } \\
\%\end{array}$ \\
\hline \multirow{2}{*}{$\begin{array}{l}\text { Lack of ICT facilities in } \\
\text { the school }\end{array}$} & Yes & $30(75)$ & $28(70)$ & $33(82.5)$ & 75.8 \\
\hline & No & $10(25)$ & $12(30)$ & $7(17.5)$ & 24.2 \\
\hline \multirow{2}{*}{$\begin{array}{l}\text { Insufficient School } \\
\text { campus }\end{array}$} & Yes & $26(65)$ & $27(67.5)$ & $34(85)$ & 72.5 \\
\hline & No & $14(34)$ & $13(32.5)$ & $6(15)$ & 27.5 \\
\hline \multirow{2}{*}{$\begin{array}{l}\text { Insufficient books in } \\
\text { Library }\end{array}$} & Yes & $22(55)$ & $32(80)$ & $29(72.5)$ & 69.2 \\
\hline & No & $18(45)$ & $8(20)$ & $9(27.5)$ & 30.8 \\
\hline \multirow{2}{*}{ Insufficient Laboratories } & Yes & $21(52.5)$ & $30(75)$ & $30(75)$ & 67.5 \\
\hline & No & $19(47.5)$ & $10(25)$ & $10(25)$ & 32.5 \\
\hline \multirow{2}{*}{ Insufficient toilets } & Yes & $21(52.5)$ & $17(42.5)$ & $24(60)$ & 51.7 \\
\hline & No & $19(47.5)$ & $23(57.5)$ & $16(40)$ & 48.3 \\
\hline
\end{tabular}

Source: Field visit; Note: Figures in the parentheses indicate the percentage

\section{Findings}

Lack of ICT Facilities in the School: The overall percentage of responses $(75.8 \%)$ agreed to this statement, of which categories of the respondents, namely, parents $(75 \%)$, teachers $(70 \%)$ and students $(82.5 \%)$ affirmed that there is lack of ICT facilities in private schools.

Insufficient School Campus: The overall percentage of responses $(72.5 \%)$ agreed to this statement of which categories of the respondents, namely, parents $(65 \%)$, teachers $(67.5 \%)$ and students $(85 \%)$ affirmed the need for sufficient school campus.

Insufficient Books in Library: The overall percentage of responses $(69.2 \%)$ agreed to this statement of which categories of the respondents, namely, parents $(55 \%)$, teachers $(80 \%)$ and students (72.5\%) affirmed insufficient books in school library.

Insufficient Laboratories: The overall percentage of responses $(67.5 \%)$ agreed to this statement of which categories of the respondents, namely, parents $(52.5 \%)$, teachers $(75 \%)$ and students $(75 \%)$ affirmed insufficient laboratories in private schools.

Insufficient Toilets: The overall percentage of responses $(51.7 \%)$ agreed to this statement of which categories of the respondents, namely, parents $(52.5 \%)$, teachers $(42.5 \%)$ and students $(60 \%)$ affirmed that there are insufficient toilets.

Table 2: Responses about Activities and Services for Students Activities and Services for Students

\begin{tabular}{|l|c|c|c|c|c|}
\hline \multicolumn{1}{|c|}{ Items } & Responses & $\begin{array}{c}\text { No. of Parents } \\
\boldsymbol{\&}(\%)\end{array}$ & $\begin{array}{c}\text { No. of Teachers } \\
\mathbf{\&}(\mathbf{\%})\end{array}$ & $\begin{array}{c}\text { No. of Students } \\
\mathbf{\&}(\mathbf{\%})\end{array}$ & $\begin{array}{c}\text { Overall } \\
\text { total } \%\end{array}$ \\
\hline \multirow{2}{*}{$\begin{array}{l}\text { Need for extra class for poor } \\
\text { performing students }\end{array}$} & Yes & $33(82.5)$ & $23(57.5)$ & $32(80)$ & 73.3 \\
\cline { 2 - 6 } & No & $7(17.5)$ & $17(42.5)$ & $8(20)$ & 26.7 \\
\hline \multirow{2}{*}{$\begin{array}{l}\text { Lack of career guidance and } \\
\text { counseling service for the students }\end{array}$} & Yes & $22(55)$ & $23(57.5)$ & $31(77.5)$ & 63.3 \\
\cline { 2 - 7 } & No & $18(45)$ & $17(42.5)$ & $9(22.5)$ & 36.7 \\
\hline \multirow{2}{*}{ Lack of co-curricular activities } & Yes & $23(57.5)$ & $23(57.5)$ & $26(65)$ & 60 \\
\cline { 2 - 7 } & No & $17(42.5)$ & $17(42.5)$ & $14(35)$ & 40 \\
\hline
\end{tabular}

Source: Field visit; Note: Figures in the parentheses indicate the percentage

\section{Findings}

Need for Extra Class for Poor-Performing Students: The overall percentage of responses (73.3\%) agreed to this statement of which categories of the respondents, namely, parents $(82.5 \%)$, teachers $(57.5 \%)$ and students $(80 \%)$ affirmed that there is the need for extra class for poor-performing students. 
Lack of Career Guidance and Counseling Service for the Students: The overall percentage of responses $(63.3 \%)$ agreed to this statement of which categories of the respondents, namely, parents $(55 \%)$, teachers $(57.5 \%)$ and students $(77.5 \%)$ affirmed that there is lack of career guidance and counseling service for the students.
Lack of Co-curricular Activities: The overall percentage of responses $(60 \%)$ agreed to this statement of which categories of the respondents, namely, parents $(57.5 \%)$, teachers $(57.5 \%)$ and students $(65 \%)$ affirmed that there is a lack of co-curricular activities in private schools of Churachandpur district.

Table 3: Responses about School Management School Management

\begin{tabular}{|c|c|c|c|c|c|}
\hline Items & Responses & $\begin{array}{c}\text { No. of Parents } \\
\text { \& (\%) }\end{array}$ & $\begin{array}{c}\text { No. of Teachers } \\
\&(\%)\end{array}$ & $\begin{array}{c}\text { No. of Students } \\
\&(\%)\end{array}$ & $\begin{array}{l}\text { Overall } \\
\text { total \% }\end{array}$ \\
\hline \multirow{2}{*}{$\begin{array}{l}\text { High Cost of } \\
\text { Education }\end{array}$} & Yes & $36(90)$ & $33(82.5)$ & $34(80)$ & 85.8 \\
\hline & No & $4(10)$ & $7(17.5)$ & $6(20)$ & 14.2 \\
\hline \multirow{2}{*}{$\begin{array}{l}\text { Low salary for } \\
\text { teachers }\end{array}$} & Yes & $25(62.5)$ & $32(80)$ & $25(62.5)$ & 68.3 \\
\hline & No & $15(57.5)$ & $8(20)$ & $15(57.5)$ & 31.7 \\
\hline
\end{tabular}

Source: Field visit; Note: Figures in the parentheses indicate the percentage

\section{Findings}

High Cost of Education: The overall percentage of responses $(85.8 \%)$ agreed to this statement of which categories of the respondents, namely, parents $(90 \%)$, teachers $(82.5 \%)$ and students $(80 \%)$ affirmed that private schools in Churachandpur district are expensive.

Low Salary for Teachers: The overall percentage of responses $(68.3 \%)$ agreed to this statement of which categories of the respondents, namely, parents $(62.5 \%)$, teachers $(80 \%)$ and students $(62.5 \%)$ affirmed that the salary of private school teachers is low.

\section{Objective 2}

To identify the prospects of private schools as perceived by parents, teachers and students in Churachandpur district, Manipur

Table 4: Responses about Prospects of Private Schools Prospects of Private Schools

\begin{tabular}{|c|c|c|c|c|c|}
\hline Items & Responses & $\begin{array}{c}\text { No. of } \\
\text { Parents } \\
\text { \& (\%) }\end{array}$ & $\begin{array}{c}\text { No. of } \\
\text { Teachers } \\
\&(\%)\end{array}$ & $\begin{array}{c}\text { No. of } \\
\text { Students } \\
\&(\%)\end{array}$ & $\begin{array}{l}\text { Overall } \\
\text { total \% }\end{array}$ \\
\hline \multirow{2}{*}{$\begin{array}{l}\text { There is Quality education in private } \\
\text { schools }\end{array}$} & Yes & $37(92.5)$ & $37(92.5)$ & $40(100)$ & 95 \\
\hline & No & $3(7.5)$ & $3(7.5)$ & $0(0)$ & 5 \\
\hline \multirow{2}{*}{$\begin{array}{l}\text { Private schools provide good services to the } \\
\text { society }\end{array}$} & Yes & $39(97.5)$ & $36(90)$ & $37(92.5)$ & 93.3 \\
\hline & No & $1(2.5)$ & $4(10)$ & $3(7.5)$ & 6.7 \\
\hline \multirow{2}{*}{$\begin{array}{l}\text { Regular monitoring of the student's } \\
\text { academic achievement in private schools }\end{array}$} & Yes & $36(90)$ & $40(100)$ & $34(85)$ & 91.7 \\
\hline & No & $4(10)$ & $0(0)$ & $6(15)$ & 8.3 \\
\hline \multirow{2}{*}{$\begin{array}{l}\text { Students studying in private schools have } \\
\text { better future prospects }\end{array}$} & Yes & $38(95)$ & $32(80)$ & $39(97.5)$ & 90.8 \\
\hline & No & $2(5)$ & $8(20)$ & $1(2.5)$ & 9.2 \\
\hline \multirow{2}{*}{$\begin{array}{l}\text { Student's discipline in private schools is } \\
\text { strictly maintained }\end{array}$} & Yes & $33(82.5)$ & $35(87.5)$ & $33(82.5)$ & 84.2 \\
\hline & No & $7(17.5)$ & $5(12.5)$ & $7(17.5)$ & 15.8 \\
\hline \multirow{2}{*}{$\begin{array}{l}\text { There is positive reinforcement(rewards) for } \\
\text { the students in private schools }\end{array}$} & Yes & $30(75)$ & $36(90)$ & $32(80)$ & 81.7 \\
\hline & No & $10(25)$ & $4(10)$ & $8(20)$ & 18.3 \\
\hline
\end{tabular}

Source: Field visit; Note: Figures in the parentheses indicate the percentage 


\section{Findings}

There is Quality Education in Private Schools: The overall percentage of responses (95\%) agreed to this statement, of which categories of the respondents, namely, parents $(92.5 \%)$, teachers $(92.5 \%)$ and students $(100 \%)$ affirmed that private schools provide quality education.

Private Schools Provide Good Service to the Society: The overall percentage of responses (93.3) agreed to this statement, of which categories of the respondents, namely, parents $(97.5 \%)$, teachers $(90 \%)$ and students $(92.5 \%)$ affirmed that private schools provide good service to the society.

Regular Monitoring of the Student's Academic Achievement: The overall percentage of responses (91.7\%) agreed to this statement, of which categories of the respondents, namely, parents $(90 \%)$, teachers $(100 \%)$ and students $(85 \%)$ affirmed that private schools keep checking on the student's academic achievement.

Students Studying in Private Schools have Better Prospects: The overall percentage of responses (90.8\%) agreed to this statement, of which categories of the respondents, namely, parents (95\%), teachers $(80 \%)$ and students $(97.5 \%)$ affirmed that students studying in private schools have better prospects.

\section{Student's Discipline in Private Schools will always} be Maintained: The overall percentage of responses (84.2) agreed to this statement, of which categories of the respondents, namely, parents $(82.5 \%)$, teachers $(87.5 \%)$ and students $(82.5 \%)$ affirmed that students discipline in private schools will always be maintained.

There is Positive Reinforcement (Rewards) for the Students: The overall percentage of responses (81.7) agreed to this statement, of which categories of the respondents, namely, parents $(75 \%)$, teachers $(90 \%)$ and students $(80 \%)$ affirmed that there is positive reinforcement for the students.

\section{Discussion}

The study observed that there is a need for ICT facilities in the private schools, which can broaden the mind of the students practically and can cope up with technological development; the use of ICT in education adds value to teaching and learning by enhancing the effectiveness of learning. There is also the need for a sufficient campus where students will have their own space, personal time, and leisure time. A bigger campus has chances for more construction which will provide more facilities for the students. Sufficient books in libraries and laboratories for the students should be mandatory and the school should take extra efforts as they are often neglected. And as much as hygiene is concern, the need for the sufficient number of toilets in the school is important. Students felt that they can be exposed to some common diseases and also to avoid lining up, as private schools set break for the students of all classes at the same time.

The study also revealed that some students does not have the capacity to acquire all the information of what they were taught in a class, so they need special or extra class to learn better. There is a need to identify the pace of learning in each student. Privatisation increases the number of certificates on the one hand and unemployment on the other hand. This is because many of them are poor in communication skill and practical knowledge in the subject. So, more and more opportunities through career guidance and counselling should be provide to the students which will prepare them to achieve their goals for life and for employment in organisations or engage in self-employment - conducting cocurricular activities where students may find their talents and interests, aside the bookish knowledge. Private schools is lacking behind in this field as most of the schools give priority to academic performance only.

The study also shows that high Cost of Education is found to be the main factor for the problem of private schools. It charges different fees to increase its income every year and it is beyond the fixed capacity of poor and middle income groups. However, the study of prospects of private schools shows that the need for quality education is much felt by parents, teachers and students to go for private schools despite of the high cost. Increase in salary of the teachers is another way of calling for qualified teachers, low salary in private schools is the reason why unqualified teachers are recruited which also affect the job security of the teachers as there is a 
risk of losing their job anytime because most of the schools does not have or maintain service rule book.

\section{Conclusion}

From the results, it is concluded that in infrastructural facilities, there is lack of ICT facilities, insufficient school campus, insufficient books in the library, insufficient laboratories, and insufficient toilet. It is also found that there is a need for extra class for poor-performing students, lack of career guidance and counseling services for the students, lack of co-curricular activities, problems of the high cost of education and low salary for teachers. On the other, it is also identified that private schools have quality education, there is regular monitoring of students' academic achievement, good discipline, and positive reinforcement, provide good service to the society, better prospects for the students. This indicates a positive perception by the stakeholders and implies a fair chance of more takers for private schools in the future. The study may also be implemented to tackle the future occurrence of problems and improve the education system as a whole.

\section{References}

Ahn, Joo-Hee, and Seung-Ju Kwak. "Comparison of Perception of Private Education of Infancy between Parents and Teachers." Journal of Korea Open Association for Early Childhood Education, vol. 22, no. 1, 2017, pp. 273-302.

Alimi, Olatunji, et al. "Teachers' Perception of Principals' Leadership Effectiveness in Public and Private Secondary Schools in Ondo State." Global Journal of Management and Business Research, vol. 11, no. 12, 2011.

Balakrishnan, Pulapre. "The Case against Privatisation of Education." The Hindu, 2014.

Beavis, Adrian. "Why Parents Choose Public or Private Schools?" Research Developments, vol. 12, 2004.

Das, Anupama Souri. "Privatisation and Higher Education in India." Mainstream, 2018.

Davis, Brent, and Linda Ellison. Strategic Marketing for Schools: How to Harmonise Marketing and Strategic Development for an Effective School. Pitman Publishing, 1997.
Foskett, Nick. "Marketing." The Principles and Practice of Educational Management. Edited by Tony Bush, and Les Bell, Paul Chapman Publishing, 2002, pp. 241-257.

Goldring, Ellen, and Kristie J. Rowley. Parent Preferences and Parent Choices: The PublicPrivate Decision About School Choice. National Research and Development Center on School Choice, 2006.

Gupta, Tania. "A Study of Perception of Students on Affordability, Financing and Privatization of Higher Education in India." International Research Journal of Human Resources and Social Sciences, vol. 3, no. 3, 2016.

https://www.academiaerp.com/blog/impact-ofprivatization-in-the-indian-education-sector/

Jain, Manish. "Public, Private and Education in India." School Education in India: Market, State and Quality. Routledge, 2018.

Kumar, Lalit, and Sudhir Kumar. "Attitude of HE Students towards Privatisation of Higher Education: A Study." Journal of Indian Education, vol. XXXVI, 2010, pp. 95-109.

Mirza, Mahrukh, and Zaibun Nisa. Privatization of Higher Education: A Study on Students' Perspective. 2020.

Nayyar, Deepak. "Globalization: What does it Mean of Higher Education?" Economic \& Political Weekly, vol. 42, no. 50, 2007.

Pedró, Francesc, et al. The Privatization of Education in Developing Countries: Evidence and Policy Implications. UNESCO, 2015.

"Privatization." Wikipedia, https://en.wikipedia.org/ wiki/Privatization

Raychaudhuri, Arohi. "Role of Private School in Primary Education in India." International Journal of Advanced Research, vol. 8, 2020, pp. 539-546.

Sarmah, Bidula. "Attitude of University Students, towards Privatization of Higher Education - A Study." Indian Journal of Applied Research, vol. III, no. 2, 2013, pp 81-83.

Sarwar, Nasir Abbas, et al. "Perception of Parents about the Role of Private Schools in District Jhang, Pakistan." International Research Journal of Social Sciences, vol. 5, no. 3, 2016, pp. 1-5. 
Sharma, Harishchandra J. Impact of Privatization on Higher Education.

Singh, Thokchom Tomba. A Study of the Management Problems of Un-aided Private Secondary Schools of Manipur. Maharaja Sayajirao University of Baroda, 2016.

Vattilthodi, Noorjahan. Students' Perception towards Privatization of Higher Education in Kerala.

Verger, Antoni, et al. The Privatization of Education: A Political Economy of Global Education Reform. Teachers College Press, Columbia University, 2016.
Yaacob, Noor Alyani, et al. "Factors Influencing Parents' Decision in Choosing Private Schools." Procedia - Social and Behavioral Sciences, vol. 153, 2014, pp. 242-253.

Yeoguk, Im, Lee Jongbok. "Perception of Students, Parents, and Teachers about Private English Education." Modern Studies in English Language \& Literature, vol. 64, no. 1, 2020, pp. 193-220.

Yousra, Ali. "The Internal and External Problems, Which Private Schools in Jordan Face." Journal of Education and Practice, vol. 5, 2014, pp. 41-45.

\section{Author Details}

Mercy Lamneichong Lhungdim, Research Scholar, Department of Education, Rajiv Gandhi University, Arunachal Pradesh, India, Email ID: mercydims@gmail.com

E. Hangsing, Professor, Department of Education, Rajiv Gandhi University, Arunachal Pradesh, India 